\title{
PROTEIN-LOSING ENTEROPATHY AS THE INITIAL MANIFESTATION OF SYSTEMIC LUPUS ERYTHEMATOSUS
}

\author{
Kharen Assunção Bezerra Galdino ${ }^{1, \star}$, Yarla Catarina Antão de Alencar ${ }^{1}$, Bruna Rufino Leão ${ }^{1}$, Bruna Aurora Nunes Cavalcante \\ Castro $^{1}$, Maria das Graças Barbosa Sousa ${ }^{1}$
}

1.Universidade Federal do Piauí, Teresina (PI), Brazil.

*Corresponding author: kharenresidencia@gmail.com

\section{BACKGROUND}

Systemic lupus erythematosus (SLE) is a multisystemic autoimmune disease. About $40 \%$ of patients have gastrointestinal tract involvement. Protein-losing enteropathy (PPE) is a rare manifestation that in half of the cases manifests as diarrhea. Usually in young women and is characterized by the appearance of edema and hypoalbuminemia in the absence of proteinuria in the nephrotic range. Enteropathy may clinically manifest with edema or cavity effusions, depending on serum albumin levels. Other symptoms that may be present are: nausea, vomiting and abdominal pain.

\section{CASE REPORT}

Female patient, white, 35 years old. She started a condition of fever, diarrhea, vomiting and poor general condition 15 days after admission, in October 2020. She sought medical assistance when ascites and bilateral pleural effusion were evidenced and relief thoracentesis was performed, being referred to this service. Admitted to the ICU, with anasarca and need for chest drainage. Reports important, unquantified weight loss, alopecia, Raynaud's phenomenon, and long-standing polyarthralgia. Complementary tests: hemoglobin $6.8 \mathrm{~g} / \mathrm{dL}, \mathrm{Ht} 22.4 \%$, leukocytes 2040, lymphocytes 204, segmented 1693, platelets $244,000 / \mathrm{mm} 3$, albumin $1.7 \mathrm{~g} / \mathrm{L}$, urea 24.2, creatinine 0.45, TGO-21, TGP-22, C3: $29.9 \mathrm{mg} / \mathrm{dL}, \mathrm{C} 4: 4 \mathrm{mg} / \mathrm{dL}$, 24-h urine proteinuria of $242 \mathrm{mg}$ in $1750 \mathrm{~mL}$. Antinuclear antibody (ANA) was 1640, antidsDNA, anti-Sm, antiphospholipid, anti-Ro/SSA and anti-La/SSB antibodies were negative. The diagnosis of SLE was established based on the criteria of the Systemic Lupus International Collaborating Clinics (SLICC 2012), alopecia, polyarthralgia, Iymphopenia, ANA and low complement. Initiated prednisone $1 \mathrm{mg} / \mathrm{kg}$. Renal and hepatic involvement was excluded as a cause of hypoproteinemia. Upper digestive endoscopy was performed, which showed pangastritis and grade $\mathrm{C}$ erosive esophagitis, and colonoscopy showed mild terminal ileitis, and a biopsy was performed. The hypothesis of protein-losing enteropathy as a cause of hypoalbuminemia was considered. There was clinical and laboratory improvement with corticosteroid therapy.

\section{CONCLUSION}

Protein-losing enteropathy is a condition characterized by excessive protein loss from the gastrointestinal tract, resulting in hypoproteinemia, edema and, in some cases, cavity effusions. This clinical situation should be suspected when there is persistent hypoalbuminemia, in the absence of significant proteinuria, preserved liver function, and adequate protein intake. The diagnosis of SLE-related protein-losing enteropathy depends on evidence of enteral protein loss, made by a combination of clinical manifestations, demonstration of protein loss through the gastrointestinal tract by CT-99 labeled albumin scintigraphy, alpha-1 antitrypsin clearance in feces, response to treatment and exclusion of other causes of hypoalbuminemia.

\section{KEYWORDS}

Systemic lupus erythematosus, Protein-losing enteropathy, Hypoalbuminemia, Diarrhea. 